\title{
SELECTED MECHANICAL PROPERTIES OF POLYPROPYLENE/TPS COMPOSITES AS A MATERIAL FOR FLOWERPOTS AND HORTICULTURE CONTAINERS
}

\author{
Agnieszka WÓJTOWICZ1, Tomasz ONISZCZUK ${ }^{1}$, Tomasz KLEPKA ${ }^{2}$, \\ Karol KUPRYANIUK ${ }^{1}$, Maciej COMBRZYŃSKI ${ }^{1}$, Francesco PICCHIONI ${ }^{3}$ \\ ${ }^{1}$ University of Life Sciences in Lublin, Department of Thermal Technology and Food Process Engineering, \\ POLAND \\ ${ }^{2}$ Department of Technology and Polymer Processing, Lublin University of Technology, POLAND \\ ${ }^{3}$ Product Technology - Engineering and Technology Institute Groningen University of Groningen, The \\ NETHERLANDS \\ E-mail of corresponding author: agnieszka.wojtowicz@up.lublin.pl
}

Keywords: polypropylene, starch, flowerpots, mechanical properties, waste management

\begin{abstract}
Thermoplastic starch (TPS) was prepared from native potato starch:glycerol:keratin (70:20:10 wt.\%) blends and processed using a modified single screw extruder at $\mathrm{L} / \mathrm{D}=16$. Recycled polypropylene was mixed with TPS at the ratio of 90:10 and 60:40 and re-granulated at various screw speeds in the extrusion-cooking process. The obtained composites were shaped into big flowerpots using an injection-molding machine. The samples collected from the external pot surface were tested with puncture tests to evaluate the mechanical properties of the material. The addition of $10 \%$ of starch-based biopolymer to the recycled PP enhanced the mechanical properties of the tested flowerpots. Selecting the proper composition and processing conditions may help to manage production of pots more sustainable. The results also confirmed the possibility to increase the TPS content up to $40 \%$ in horticultural containers and the option of processing such composites with injection-molding as more environmentally friendly than using conventional polymers.
\end{abstract}

\section{INTRODUCTION}

Polymeric composites made from renewable resources, such as starch, flax, hemp or annual plant straw, are potentially the most environmentally friendly materials (Ammala et al. 2011). The demand for new biomaterials is due to, among others, ecological awareness of consumers - who are more likely to choose products from environmentally friendly materials - better and better properties of bioplastics as well as the growing availability of goods made of natural materials or with their addition (Mendes et al. 2016, Vieira et al. 2011). An enormous interest in environmentally friendly materials has inspired the search for new solutions and technologies for the production of such types of biomaterials. The increasing application of plant raw materials for industrial purposes represents an economic opportunity for agriculture (Janssen and Mościcki 2009). It contributes to the functioning of sustainable agriculture and gives the opportunity to utilize surplus starch and straw of annual plants. It also brings a number of benefits (e.g. legal) to manufacturers and users of composite products with added natural resources (Oliveira et al. 2017). In recent years, starch has become one of the basic natural resources used in the production of biodegradable materials (Yu et al. 2013). Biopolymers can be obtained by mixing starch with some plasticizers (often glycerol) in order to let the material melt at a temperature lower than the starch degradation temperature (Da Róz et al. 2011; Morán et al. 2013; Mościcki et al. 2013). This form of starch is known as thermoplastic starch (TPS). Although thermoplastic starch is a cheap polymer, it has no satisfactory processing capability (Ning et al. 2007). Products based on starch are highly water sensitive. So far, the main challenge has been to replace traditional polymers with biodegradable materials offering the desired stability over the life of the product and 
having a positive impact on the environment after degradation. The use of different blends of biopolymers with traditional cheaper plastics is thus seen as a compromise to maintain the balance between the properties, costs and biodegradability of materials (Martins and Campomanes Santana 2016; Roy et al. 2011). Biodegradable biocomposites produced from thermoplastic starch enriched with various functional additives in order to accelerate the decomposition of polymer-starch composites can be used to produce environmentally friendly containers by means of the high-pressure injection-molding technique (Oniszczuk et al. 2016). The aim of the study was to obtain some new composite containers for gardening applications using thermoplastic starch as an additive to improve material degradation. Moreover, some mechanical properties of this new flowerpot-shaped polypropylene/TPS composite were evaluated.

\section{MATERIALS AND METHODS}

Potato starch (PEPEES S.A., Łomża, Poland), glycerol (POCH S.A. Lublin, Poland) and keratin hydrolyzate (Proteins, Łódź, Poland) were used as thermoplastic starch (TPS) components (Rejak et al. 2012). Thermoplastic starch (TPS) was prepared from native potato starch:glycerol:keratin (70:20:10 wt.\%). The raw materials for thermoplastic starch were mixed and TPS granulates were processed using the modified single screw extruder TS-45 (Metalchem, Gliwice, Poland) at $\mathrm{L} / \mathrm{D}=16$ (Juśko et al. 2009). The operating parameters were as follows: the screw speed during processing: $80 \mathrm{rpm}$, the temperature range: $80-110^{\circ} \mathrm{C}$, the forming die of $2 \mathrm{~mm}$ in diameter. Small pellets (granulates) were collected by a cutting knife and cooled down at room temperature. Recycled polypropylene PP granulate $(\operatorname{MFR}(190,5 \mathrm{~kg}) 16 \mathrm{~g} / 10 \mathrm{~min})$ purchased from AKPOL (Kraśnik, Poland) was used as the basic polymer material. Polypropylene was mixed with TPS at two composition ratios: PP/TPS 90:10 and 60:40. The obtained mixtures were processed into composites using the above-mentioned single screw extruder at two screw speeds: 50 and $100 \mathrm{rpm}$. The obtained composites were shaped into $20 \mathrm{~L}$ flowerpots by means of the injection-molding technique. The injection-molding machine S+550-3550 (STORK IMM, Hengelo, the Netherlands) was filled with PP/TPS composites, and the formation process was performed at $210^{\circ} \mathrm{C}$ for $12 \mathrm{sec}$ of process time. Finished flowerpots were collected for further tests. The mechanical properties were tested with the universal testing machine ZWICK Z020/TN25 (Ulm, Germany) with $20 \mathrm{kN}$ load cell. The samples of composite flowerpots of 100x100 mm were cut out from the central part of the outer surface of the pots. Penetration tests were performed using an oval penetrator with $5 \mathrm{~mm}$ in diameter with the test speed of $10 \mathrm{~mm} \cdot \mathrm{min}^{-1}$. The sample was put on the machine's working table and punctured to complete destruction. Some selected mechanical properties were evaluated, such as the maximum force, Young modulus, elongation at maximum force, elongation at break, work at maximum force, and work at break. The Young modulus was evaluated by a secant with the speed of $10 \mathrm{~mm} \cdot \mathrm{min}^{-1}$. Forcedisplacement curves were recorded and analyzed with the testXpertII v3.3 software. The mechanical properties were assessed in triple for each composite used the flowerpot component.

\section{RESULTS AND DISCUSSION}

The PP/TPS composites were used as the input material for flowerpots due to the TPS property of accelerating the decomposition of polymer-starch products in soil. Besides the environmental advantages, the mechanical properties and resistance to break are extremely important for horticultural purposes. Pots processed with the injection-molding 
technique based on recycled polypropylene with the addition of TPS need to display sufficient mechanical properties required for the proper protection and cultivation of plants. An advantage of this solution is the re-use of polypropylene due to its recyclability and the application of TPS as a natural component which may improve the decomposition of containers after use. Tests performed to evaluate the mechanical properties showed a significant effect of both the composition of the mixture and the screw speed applied during the processing of PP/TPS composite granulates. Some typical curves from puncture tests are presented in Fig. 1. For PP/TPS composites, they depend on the level of addition of thermoplastic starch and the screw speed applied during the processing of composites. There are significant differences in the behavior of samples in puncture test. The samples of PP/TPS with 10\% of thermoplastic starch (Fig. 1a and 1b) were stiffer and much harder than with the addition of $40 \%$ of biopolymer (Fig. 1c and 1d).
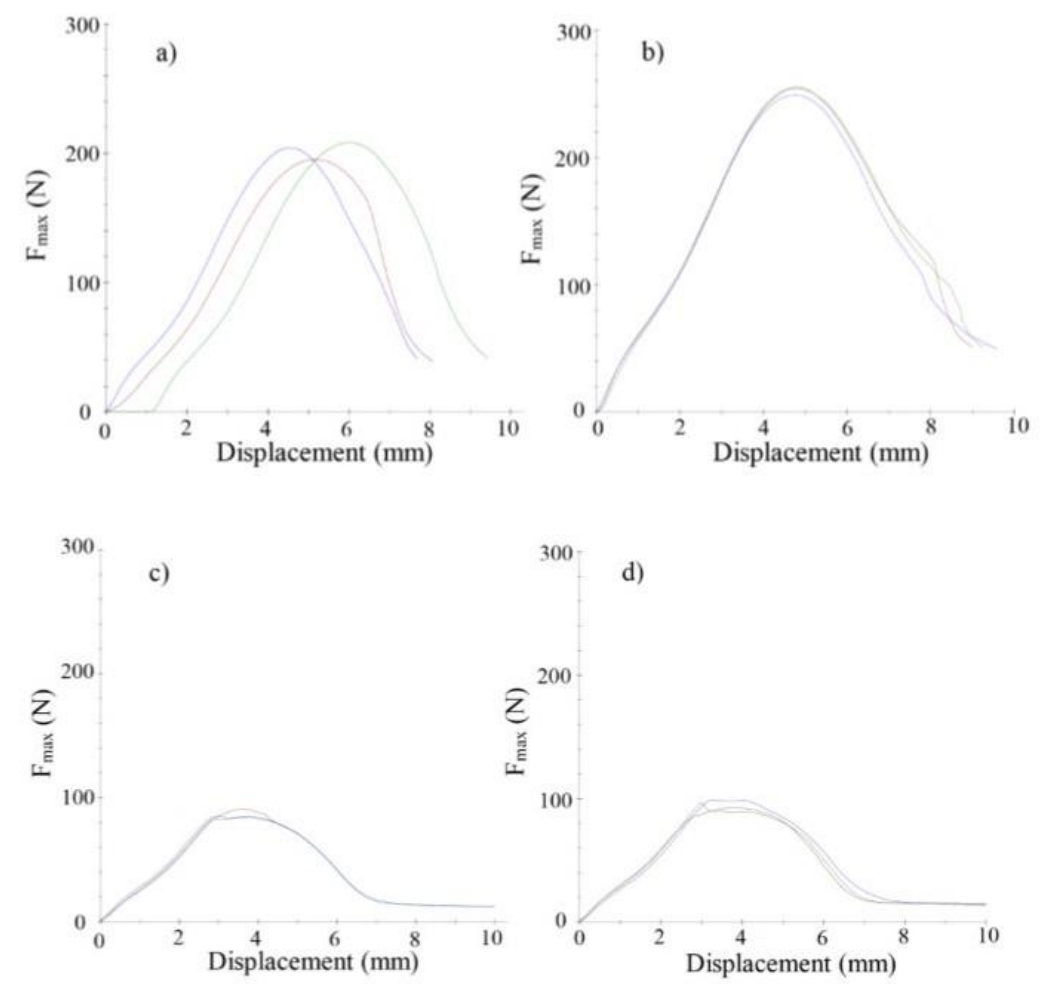

Fig. 1. Typical curves from the puncture tests of PP/TPS composites processed at various screw speeds: a) 90:10 - $50 \mathrm{rpm}$, b) 90:10 - $100 \mathrm{rpm}$, c) $50 \mathrm{rpm}$ 60:40, d) $100 \mathrm{rpm}$ 60:40.

One of the most important parameters of horticultural containers is hardness expressed as a maximum force required to break the sample. The results shown in Fig. 1 prove that the addition of $40 \%$ of thermoplastic starch to composite blends decreased hardness of the tested materials significantly. Moreover, PP/TPS 60:40 samples did not differ much (around $10 \mathrm{~N}$ ) across the screw speeds applied during the processing of composites compared with PP/TPS 90:10 where the difference was about $50 \mathrm{~N}$. Similar observations were made for the Young modulus values. This feature also showed values that were twice as high for the samples prepared on the basis of PP/TPS 90:10 composites (Fig. 2). Higher hardness and Young modulus were recorded during the test of pots made from granulates processed at $100 \mathrm{rpm}$. A higher screw speed is likely to improve the intensity of treatment inside the extruder barrel, so these composites could be more consolidated offering greater hardness and resistance to stress. 


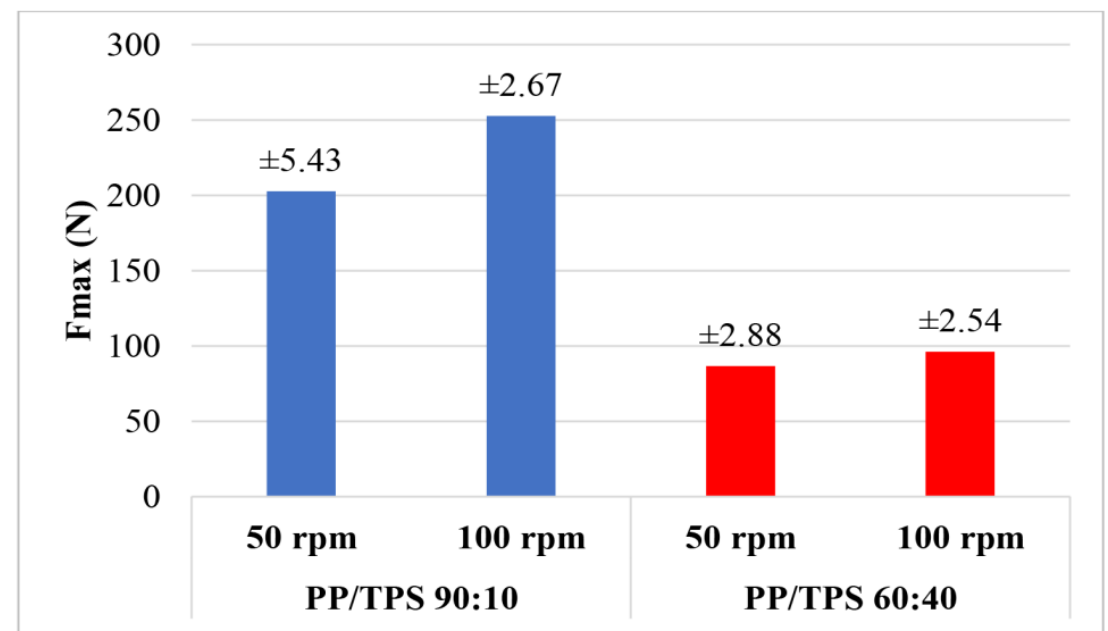

Fig. 2. $F_{\max }$ values of PP/TPS composite during puncture test depend on the composition and screw speed applied during processing (mean \pm standard deviation).

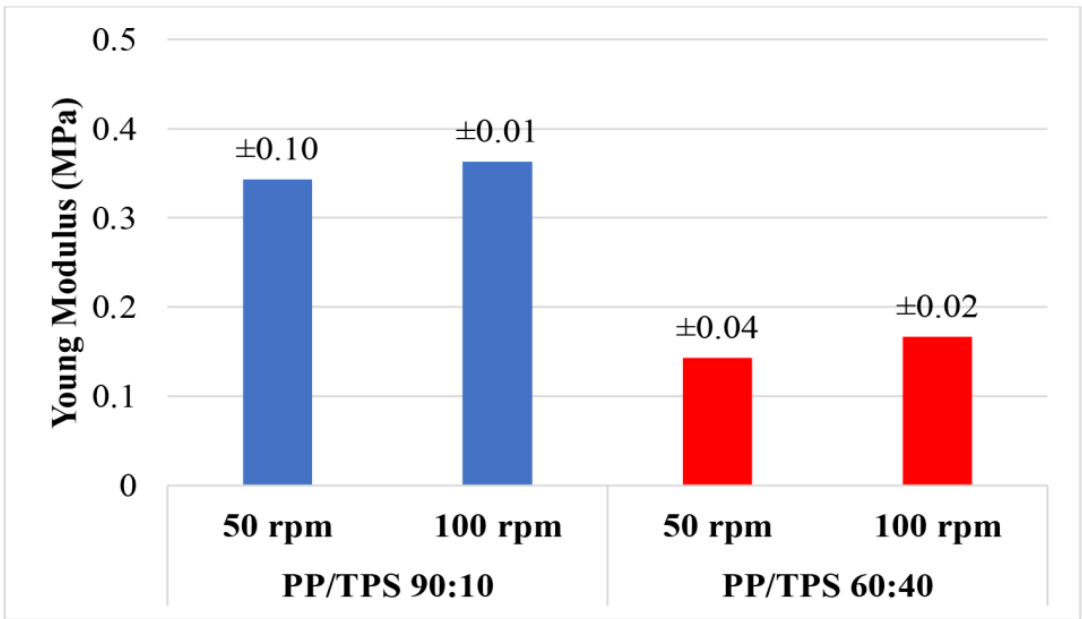

Fig. 3. Young modulus of PP/TPS composite during puncture test depend on the composition and screw speed applied during processing (mean \pm standard deviation).

The test results for elongation, as presented in Fig. 4, indicate a more intensive elongation of samples made with PP/TPS 90:10 composites, similarly to the results for hardness. Pots processed with composites made from recycled polypropylene and thermoplastic starch are not brittle but elastic, so the elongation varied from 188 to $281 \%$ vs. initial thickness. A higher elasticity of samples was reported for those made from composites extruded at lower rpm irrespectively of the recipe applied. More intensive thermomechanical treatment increased hardness and lowered the elasticity of the tested materials. If the samples were harder and less elastic, the work required to break them was greater, as shown in Fig. 5. 


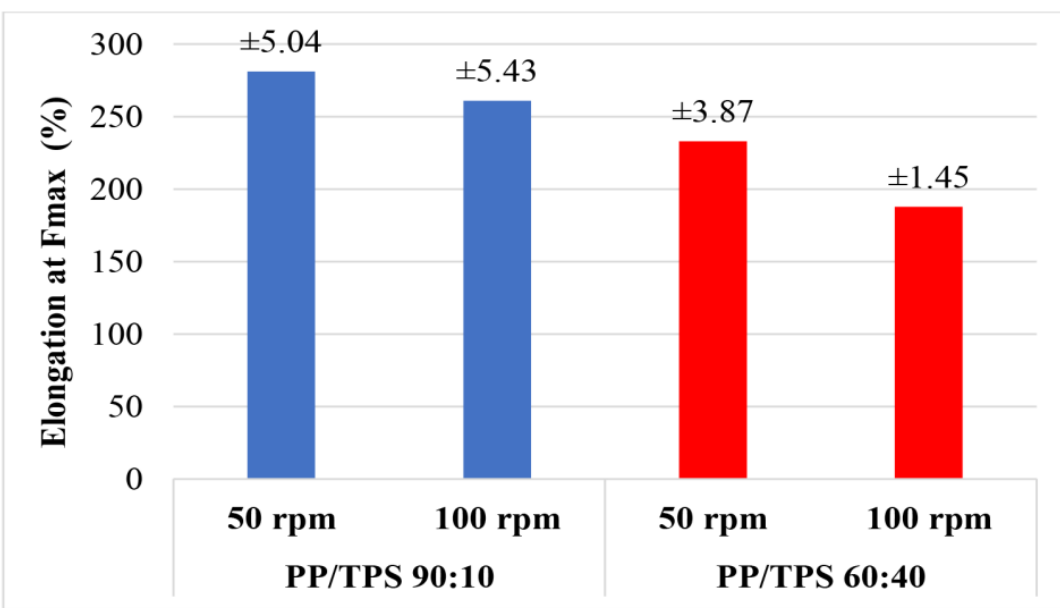

Fig. 4. Elongation at $\mathrm{F}_{\max }$ of PP/TPS composite during puncture test depends on the composition and screw speed applied during processing (mean \pm standard deviation).

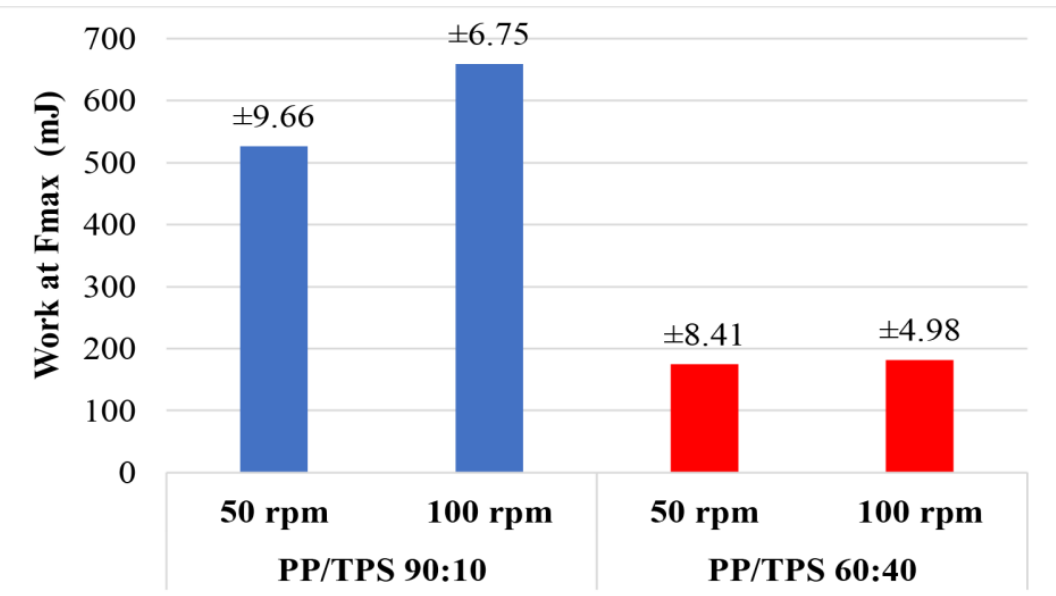

Fig. 5. Work at $\mathrm{F}_{\max }$ of PP/TPS composite during puncture test depends on the composition and screw speed applied during processing (mean \pm standard deviation).

The lower values (almost three times) of puncture work were recorded in breaking pots made from the composites of PP/TPS 60:40 as correlated with their lower durability and elasticity. These composites made the material weaker as in the case of a relatively high number of starchy components in blends. For mixed polymer/starch composites, starch is usually added up to 10\% (Martins and Campomanes Santana 2016; Ning et al. 2007), and the presented results confirmed this level as better for the quality of containers.

\section{CONCLUSIONS}

The discussed results showed the options of use of recycled PP/TPS composites for the production of containers by means of the injection-molding technique. The variable conditions of extrusion-cooking applied to prepare the granulate of PP/TPS composites had an impact on hardness, durability, and elasticity of achieved materials. The application of TPS as an additive to recycled polypropylene could be an effective solution in improving the sustainability of plastic waste management. TPS is biodegradable, so its addition to composites with polymers could accelerate the decomposition of this material in soil. An addition of $10 \%$ of starch-based biopolymer to recycled PP produces better mechanical properties, such as greater hardness, Young modulus and elasticity of the tested flowerpots, than $40 \%$ of the additive. Nevertheless, the results confirmed the 
possibility of effective materials and processing management during producing flowerpots and horticultural containers with the TPS content of up to 40\%. Such composites are also processable with injection-molding. Based on these findings, a new range of environmentally friendly composites has a potential to be applied in garden containers.

\section{REFERENCES}

Ammala, A., Bateman, S., Dean, K., Petinakis, E., Sangwan, P., Wong, S., Yuan, Q., Yu, L., Patrick, C., Leong, K.H. (2011). An overview of degradable and biodegradable polyolefins. Progress in Polymer Science, 36, 1015-1049.

Carvalho, A.J.F., Curvelo, A.A.S., \& Gandini, A. (2005). Surface chemical modification of thermoplastic starch: Reactions with isocyanates, epoxy functions and stearoyl chloride. Industrial Crops and Products, 21(3), 331-336.

Da Róz, A.L., Zambon, M.D., Curvelo, A.A.S., \& Carvalho, A.J.F. (2011). Thermoplastic starch modified during melt processing with organic acids: The effect of molar mass on thermal and mechanical properties. Industrial Crops and Products, 33(1), 152-157.

Janssen, L., \& Moscicki, L. (Eds.) (2009). Thermoplastic Starch. Wiley-VCH, Germany.

Juśko, S., Mościcki, L., \& Wójtowicz, A. 2009. Design Patent PL64690Y1: Sekcja chłodząco-formująca (Cooling-forming section), Wiadomości Urzędu Patentowego, 12, 3035.

Martins, A.B., \& Campomanes Santana, R.M. (2016). Effect of carboxylic acids as compatibilizer agent on mechanical properties of thermoplastic starch and polypropylene blends. Carbohydrate Polymers, 135, 7985.

Mendes, J.F., Paschoalin, R.T., Carmona, V.B., Sena Neto, A., Marques, A.C.P., Marconcini J.M., Mattoso, L.H.C., Medeiros, E.S., \& Oliveira J.E. (2016). Biodegradable polymer blends based on corn starch and thermoplastic chitosan processed by extrusion. Carbohydrate Polymers, 137, 452-458.

Morán, J.I., Cyras, V.P., \& Vázquez, A. (2013). Preparation and characterization of three different derivatized potato starches. Journal of Polymers and the Environment, 21(2), 395-404.

Mościcki, L., Mitrus, M., Wójtowicz, A., Oniszczuk, T., Rejak, A., \& Janssen, L.P.B.M. (2012). Application of extrusion-cooking for processing of thermoplastic starch (TPS). Food Research International, 47(2), 291-299.

Ning, W., Jiugao, Y., Xiaofei, M., \& Ying, W. (2007). The influence of citric acid on the properties of thermoplastic starch/linear low-density polyethylene blends. Carbohydrate Polymers, 67(3), 446-453.

Oliveira, T.A., Oliveira, R.R., Barbosa, R., Azevedo, J.B., \& Alves, T.S. (2017). Effect of reprocessing cycles on the degradation of PP/PBAT-thermoplastic starch blends. Carbohydrate Polymers, 168, 52-60.

Oniszczuk, T., Wójtowicz, A., Mościcki, L., Mitrus, M., Kupryaniuk, K., Kusz, A., \& Bartnik, G. (2016). Effect of natural fibres on the mechanical properties of thermoplastic starch. International Agrophysics, $30(2), 211-218$.

Rejak, A., Mościcki, L., Wójtowicz, A., Oniszczuk, T., Mitrus, M., \& Gładyszewska B. (2012). Influence of keratin addition on selected mechanical properties of TPS film. TEKA. Commission of Motorization and Energetics in Agriculture, 12(1), 219-224.

Roy, S.B., Ramaraj, B., Shit, S.C., \& Nayak, S.K. (2011). Polypropylene and potato starch biocomposites: Physicomechanical and thermal properties. Journal of Applied Polymer Science, 120(5), 3078-3086.

Vieira M.G.A., Altenhofen da Silva M., Oliveira dos Santos, L., \& Beppu M.M. (2011). Natural-based plasticizers and biopolymer films: A review. European Polymer Journal, 47, 254-263.

Yu, F., Prashantha, K., Soulestin, J., Lacrampe, M.F., \& Krawczak, P. (2013).

Plasticized-starch/poly(ethylene oxide) blends prepared by extrusion. Carbohydrate Polymers, 91, 253261. 